\title{
Scientific Competencies of Kindergarten Teachers for Identifying Children with Special Needs and Their Attitudes towards Them - Survey Study in Najran, KSA
}

\author{
Mervat Ragab Saber (Corresponding author) \\ Assist. Professor of Special Education, College of Education, Najran University \\ K.S.A P.O. Box 1988, Najran 61441, KSA \\ Tel: 966-580490580. E-mail: dr_mervetragab@yahoo.com
}

\author{
Fayza A. Yousf \\ Lecturer in Kindergarten, College of Education, Najran University \\ K.S.A, P.O. Box 1988, Najran 61441, KSA
}

Tel: 966-534219001. E-mail: fayzayousf @yahoo.com

\begin{abstract}
Received: February 13, 2016 Accepted: February 29, 2016 Published: March 28, 2016
doi:10.5296/ire.v4i1.9012ＵRL: http://dx.doi.org/10.5296/ire.v4i1.9012
\end{abstract}

The research is funded by the Deanship of the Scientific Research at Najran University (NU/SHED14/151)

\begin{abstract}
The present study is an attempt to find out the availability of scientific competencies among kindergarten female teachers for identifying children with special needs in Najran and to identify the correlation between the scientific competencies to identify children with special needs and the attitude towards them. The variables utilized in this study are (specialization, years of experience, and number of courses). The study sample consists of (150) kindergarten teachers in Najran for the academic year (2014/2015). For achieving the purposes of the study, the two authors utilized a questionnaire to measure the scientific competencies, which comprised (43) items and another questionnaire to measure the attitude towards children with special needs. The study resulted that the kindergarten teachers enjoy scientific competencies
\end{abstract}


related to the skill of identifying the special-needs child and the skill of dealing with that child. There is also a positive relationship between the scores of the sample of the scientific competencies for the special-needs child and their scores on the scale of the attitude towards the child, as well as there are statistical differences for the scales of competencies and attitudes towards the special-needs child in favor of the specialization of Kindergarten and those of medium work experience (6-10) years.

Keywords: competencies, kindergarten teachers, children with special needs, Najran

\section{Introduction}

All countries nowadays have a great interest in the kindergarten stage for the recognition of the main role of that stage in the upbringing of the individual and building his/her personality from various aspects. As a result of this international interest, different Arabic countries undertook kindergarten education system as a part of their educational programs.

The interest in the early childhood, in the 21 st century, has become one of the priorities of the educational and pedagogical objectives on the Arabic and international level (Abo-Harb, 2005), so the concerned colleges qualified Kindergarten teachers by designing educational programs according to the attitude of skills and competencies, as the teachers will use these skills and competencies to develop the abilities of the children during their education (Quebec, 2002).

Altomy (2005) defines competency as "a group of self-generated resources (knowledge, skills, abilities, behaviors, strategies, evaluations ...) which are arranged in a compound structure (system) that allows integrating and changing them in specific situations into proper accomplishment".

In a parallel way, people with special needs got great care and interest on the national and international level to achieve equalization of educational opportunities for all people of society. With the appearance of the interest in that category and the necessity of the provision of educational and pedagogical care for them, and as they differ from normal children in one or more of the psychological, physical, sensory, emotional, behavioral and social characteristics, there was a need for inclusion of some modifications of the programs of qualifying teachers from quantitative and qualitative perspective. There is no doubt that the good qualification and persistent training contribute greatly to the success of the teacher in performing her role effectively as well as the development of her ability of early detection of disability and the attempt to decrease it, as this stage is considered preventive and therapeutic. (Al-Haroun, 2006)

As the attitudes of male and female teachers are affected by the psychological, physical and social characteristics of people with special needs, they adopt negative attitudes towards that category. There is no doubt that the integration of children with special meeds in the regular schools would be a failure unless teachers accepted them, so the formation of positive attitudes towards the abnormal child is necessary for the success of the educational process, that is why the activation of the role of the kindergarten teacher is necessary for the identification of her attitudes and viewpoints in a way that is useful for that category 
(Alsaiegh, 2001). Al-Shakhs (1990) affirmed that the information related to people with special needs plays an important role in changing the attitudes of teachers to be positive. According to the importance of studying the attitudes and their effect on the educational process, many researchers handled them for example the studies of (Hawkins, 1991; Block \& Rizzo, 1995); Katie \& Ron, 1995; Alfaiez, 1996; Jawarneh, 2003; Alsamadi, 2007).

Therefore, the current study seeks to identify the availability of the scientific competencies for the kindergarten teachers that qualify them to identify children with special needs, and their attitudes towards dealing with them in some kindergarten schools in Nagran in the kingdom of Saudi Arabia.

\subsection{Statement of the Problem}

The present study conducted by the two authors to identify to what extent the kindergarten teachers have scientific competencies necessary for identifying children with special needs in Nagran, KSA, and their attitudes towards these children. So, the following question sums up the problem of the study:

What is the extent of the availability of the scientific competencies among Kindergarten teachers necessary for identifying the child with special needs in the kindergartens of Najran and their attitudes towards that child? Sub questions appear from the main one of the study:

1) What is the level of the availability of the skill of identifying the child with special needs among Kindergarten teachers?

2) What is the level of the availability of the skill of dealing with the child with special needs among Kindergarten teachers?

3) Are there statistical differences among the means of the responses of Kindergarten teachers on the basis of the scale of scientific competencies due to the variable of (specialization, years of work experience, and courses in special needs)?

4) Are there statistical differences among the means of the responses of Kindergarten teachers on the basis of the scale of the attitude towards the child with special needs due to the variable of (specialization, years of work experience, and courses in special needs)?

5) Are there statistical correlations among the scores of the Kindergarten teachers on the basis of the scale of scientific competencies and their scores on the basis of the attitude towards the child with special needs?

\subsection{Objectives}

1) Determining the level of the availability of the scientific competencies in the domains of (skill of identifying the child with special needs, skill of dealing with the child with special needs) among Kindergarten teachers in Najran.

2) Identifying the attitudes of Kindergarten teachers towards the child with special needs in Nagran.

3) Identifying the statistical differences among the responses of Kindergarten teachers on the basis of the scale of scientific competencies and the effect of (specialization, years of work experience and number of courses). 
4) Detecting the differences of the nature of attitudes of Kindergarten teachers towards the child with special needs due to the variables of (specialization, years of work experience and number of courses).

5) Identifying the nature of correlation between scientific competencies among female teachers for learning difficulties in Nagran and their attitudes towards the child with special needs.

\subsection{Significance of the Study}

First: Theoretic significance: This study gains its importance due to the importance of the target group which is the group of special needs. Also, this study is considered new addition and scientific enrichment in the field of scientific research in relation to skills of identifying the child with special needs among Kindergarten teachers, benefitting from the study in developing scientific competencies for those teachers, for meeting needs of those with special needs. This study may form a basis on which the subsequent researches are based in the Kingdom of Saudi Arabia.

Second: Applied significance: we can get benefit from the research findings in preparation of guiding and educational programs for those who are responsible for educational and pedagogical process; also this study may help the responsible people in the Ministry of Education in the Kingdom of Saudi Arabia in supporting the attitudes of kindergarten teachers towards the children with special needs, this allows them to focus on positive aspects of these attitudes and try to exert efforts for treatment of the negative aspects.

\section{Literature Review}

Albehery (2004) suggested a model for integration of children with mental retardation, and behavioral and emotional disorders with normal children. This study indicated the level of possibility of including children with special needs in regular schools in Riyadh and application of Full Inclusion System as a suggested model consisting of three components: philosophy of effective optimal integration, educational levels (kindergarten program, academic preparation program and professional qualification program), and map of operations which includes stage of preparation, stage of execution and stage of evaluation.

Alharon (2006) made a comparison for identifying the training and qualification systems for kindergarten teachers for children with special needs in Arab Republic of Egypt, United States of America, and Kingdom of Jordan, as well as the identification of similarities and differences between them to develop these systems in Arab Republic of Egypt. The study concluded that there is a lack of integrated, specific and clear policy for the qualification of kindergarten teachers for children with special needs and training them in a way that matches the nature of their work in Arab Republic of Egypt.

A study by Abdul-Haq (2014) aims to investigate the degree of availability of the general basic educational skills in kindergarten teachers in Jordan from the standpoint of the teachers themselves, and to identify the effect of the teachers' major and the Kindergarten type (public/private) on the availability of these educational skills. The results indicated that all the 
questionnaire items are educational skills required for kindergarten teachers from the standpoint of the teachers themselves, and that there are no statistically significant differences $(\alpha \leq 0,05)$ due to kindergarten type, whereas there are statistically significant differences $(\alpha \leq$ $0,05)$ due to teachers' major (educational/otherwise) in favor of the educational majors. The study recommends the need to hold training courses for kindergarten teachers in modern methods of dealing with children, in addition to limiting working in kindergartens to graduates of the educational sciences faculties.

James, et al. (2009) aims at providing a perception about the way of preparing the kindergarten children according to the skill of competencies in Canada; the research showed that domains of preparing the kindergarten children should start from what children do in activity room, in addition to other technical criteria that should be taken into consideration.

Al-Deeb(2013) mad some recommendation for success of integration process in the study of problems that face the integration process of children with special needs, one of the most important recommendations is that the integration starts from the start of kindergarten stage, preparation of courses that are based on techniques of dealing with children with special needs before and during the teaching provided by teachers of kindergarten, preparation of specialized professionals in the field of children with special needs in a way that improves their social skills, modification of attitudes of teachers and normal children towards children with special needs, providing children with special needs with primary social skills.

The study of Kis-Glavas, Lelia; et al. (1996) examined the attitudes of 194 teachers in 17 regular primary schools in the city of Zagreb (Croatia) and the surrounding area about the integration of children with intellectual or other developmental disabilities. In addition to providing demographic data, the teachers completed a 21-item questionnaire with questions that addressed: (1) their attitudes toward pupils with developmental difficulties; (2) attitudes toward integration of these pupils; (3) familiarity with the characteristics and needs of pupils with developmental difficulties; and (4) teacher readiness to get involved in improving the integration process. Factor analysis identified five factors, all of which indicated predominantly negative attitudes by teachers toward integration. The factors examined were: (1) recognition of advantages of integration for pupils with developmental difficulties; (2) attitude toward regular schools' equipment; (3) effects of integration on other pupils; (4) familiarity with characteristics and needs of special needs students; and (5) attitudes toward partial integration. The most positive attitudes were expressed by female teachers, under age 36 , and with less than 5 years of experience. The most negative attitudes were expressed by male teachers, over age 36, with work experience of more than 15 years and the subject teachers.

Alfaiez (1996) conducted a study in which she aimed to recognize the pattern of attitudes of kindergarten teachers towards integration of children with special needs with normal children in kindergarten institutions. $50 \%$ of study population was selected from governmental and private kindergarten teachers in Riyadh; total of study sample is (706) teachers; the study concluded that attitudes of kindergarten teachers towards integrating people with special needs with normal children in kindergarten institutions are characterized with objectivity with 
little positive. The teachers specialized in kindergarten and special education have more positive attitudes towards integration than teachers that have educational or non-educational university degree, or than those who have no university degree; teachers who apply integration is more positive than those who do not apply it.

Curran (1999) hypothesized that students in a course on mental retardation (MR) who had had extended contact with retarded people would achieve more favorable attitudes toward mental retardation than students without similar contact. Students enrolled in a Psychology of Mental Retardation class were randomly assigned to a control group $(n=29)$ or an experimental group $(n=59)$; a group of business students $(n=64)$ served as a second control group. All students provided demographic information and completed a community living attitude scale, that measures four attitudes (empowerment, exclusion, sheltering, similarity) toward people with MR, at the beginning and end of the semester. Experimental students completed 20 hours of community service with people with MR and kept reflective journals. The study found no between-group pretest differences between experimental and control groups; however, differences were noted between those selecting the MR course and those in the business course (those selecting the MR course had had more interaction, scored higher on the empowerment and similarities scales, and lower on the exclusion scale). Students' previous school experiences with people with MR did not predict attitudes or attitude change. However, previous experience with mentally retarded people did predict posttest results for control group students, with those having the least experience reporting higher exclusion scores.

Cook et al. (2000) conducted a study to measure the attitudes of teachers towards students with special needs in regular schools. the study sample consists of (70) teachers who teach for primary school students; the study findings indicated that attitudes of teachers towards students with mental disabilities were positive, especially in case the level of disability was simple that the more experience of teachers increased, the more their attitudes were positive.

Praisner (2003) conduct a survey of 408 elementary school principals to investigate relationships regarding attitudes toward inclusion, variables such as training and experience, and placement perceptions. Results indicate that about 1 in 5 principals' attitudes toward inclusion are positive while most are uncertain. Positive experiences with students with disabilities and exposure to special education concepts are associated with a more positive attitude toward inclusion. Further, principals with more positive attitudes and/or experiences are more likely to place students in less restrictive settings. Differences in placement and experiences were found between disability categories. Results emphasize the importance of inclusionary practices that give principals positive experiences with students of all types of disabilities as well as provide principals with more specific training.

\section{Hypotheses}

1) Kindergarten teachers have reasonable level of scientific competencies related to identification of child with special needs (skill of identifying the child with special needs - skill of dealing with the child with special needs). 
2) There are statistical significant differences at the level of (0.05) between the means of the responses of kindergarten teachers on the scale of scientific competencies for identifying the child with special needs due to the variables of (specialization, years of work experience, and number of courses).

3) There are statistical significant differences at the level of (0.05) between the means of the responses of kindergarten teachers on the scale of the attitude towards the child with special needs due to the variables of (specialization, years of work experience, and number of courses).

4) There is a positive correlation between the scores of Kindergarten teachers for scientific competencies related to the child with special needs and their scores on the scale of the attitude towards that child.

\section{Methodology}

The current study depends on comparative descriptive approach, as it is one of the most suitable approaches for achieving the purpose of this study.

\subsection{Participants}

The study sample consists of (150) kindergarten teachers in public governmental schools in Najran for the academic year 2014/2015. Table (1) provides sample distribution according to the variables of the study: Specialization, years of work experience, and number of training courses.

Table (1). Distribution of the sample in the light of the study variables

\begin{tabular}{cccc}
\hline Variable & Variance Level & Number & Percentage \\
\hline Specialization & Kindergarten & 96 & $64 \%$ \\
& Other & 54 & $36 \%$ \\
\hline Years of work experience & $1-5$ & 60 & $40 \%$ \\
& $5-10$ & 67 & $45 \%$ \\
& $10-15$ & 23 & $15 \%$ \\
\hline \multirow{2}{*}{ Number of training courses } & $1-5$ & 66 & $44 \%$ \\
& $6-10$ & 84 & $56 \%$ \\
\hline
\end{tabular}

Table (1) shows that the percentage of kindergarten teachers is higher than other specializations, as their percentage represents $64 \%$, all female teachers got training courses in the field of special needs.

\subsection{Instrument}

1) Scale of scientific competencies required for identifying the child with special needs among kindergarten teachers (prepared by the two authors)

A questionnaire for the current study was developed in light of literature review in the area of scientific competencies of kindergarten teachers for identifying the child with special needs. 
The two authors prepared a questionnaire based on a five-point Likert scale, the questionnaire consists of (42) items distributed to two domains (Identifying the child with special needs and the teacher's dealing with the child with special needs).

Reliability: the value of Alpha Cronbach was (0.857) for the scale as a whole, which is statistically significant at the level of (0.01). Half-split was calculated, and reliability coefficient was $(0.844)$ for Spearman-Brown and (0.867) for Gateman, that means that the questionnaire is of high level of reliability as the following table indicates:

Table (2). Values of reliability by using half-split method for the domains of the questionnaire of scientific competencies as a whole and the sub domains and the scale of attitude

\begin{tabular}{ccc}
\hline Domains & $\begin{array}{c}\text { Spearman-Brown correlation } \\
\text { coefficient }\end{array}$ & $\begin{array}{c}\text { Gateman correlation } \\
\text { coefficient }\end{array}$ \\
\hline Identifying the child with special needs & 0.808 & 0.835 \\
Teacher's dealing with the child with special needs & 0.828 & 0.882 \\
Scale of the attitude of kindergarten teacher & 0.895 & 0.883 \\
towards the child with special needs & & 0.867 \\
Total & 0.844 & \\
\hline
\end{tabular}

Validity: The questionnaire reviewed and evaluated by (11) reviewers and academic professors specialized in special educational and educational psychology, who rated the clarity and appropriateness of the scale statements. Based on the group's observations and suggestions, necessary adjustments were made and some phrases were reworded. Professors' percentage of agreement reached $80 \%$ after implementing their suggestions, so the number of items in the questionnaire is (42) items rather than (47) distributed to two domains. The two authors used Candle coefficient for validity of internal consistency.

Table (3). Candle coefficient for validity of internal consistency for the domains of scientific competencies and scale of the attitude of kindergarten teachers

\begin{tabular}{cc}
\hline Domains & Candle coefficient \\
\hline Identifying the child with special needs & 0.818 \\
Teacher's dealing with the child with special needs & 0.828 \\
Scale of the attitude of kindergarten teacher towards the child with special needs & 0.895 \\
Total & 0.847 \\
\hline
\end{tabular}

Table (3) shows that Candle coefficient for the domains and the scale as a whole is (0.847) which is statistically significant at the level of $(0.01)$. This value is high in relation to this type of validity and it emphasizes the total internal consistency.

2) Scale of the attitude of kindergarten teachers towards the child with special needs (prepared by the two authors) 
The scale consists of (34) items in its final form based on Likert method. The questionnaire prepared according to "Yuker" scale, "Bogrados" scale, and scale of attitudes towards people with special needs (Al-Qaryouty, 1998), besides the theoretical framework and literature review which handled this variable for different samples.

Table (4). Level of agreement among reviewers on the questionnaire

\begin{tabular}{|c|c|c|c|}
\hline & \multicolumn{2}{|c|}{ Number of reviewers } & \multirow{2}{*}{$\begin{array}{l}\text { Agreement } \\
\text { percentage }\end{array}$} \\
\hline & Agreement & Disagreement & \\
\hline $\begin{array}{l}\text { Scale of the attitude of kindergarten teacher towards the } \\
\text { child with special needs }\end{array}$ & 9 & 2 & $81.8 \%$ \\
\hline
\end{tabular}

Reliability: the two authors calculated the half split with spearman Brown and Gateman methods, which indicated that the coefficient of the two halves is positive and their statistical value is (0.895) on Spearman-Brown method, and for Gateman is (0.883). Also, Alpha-Cronbach coefficient was calculated and its value is (0.851); these are high values, which are satisfying for the reliability of scale as shown in table (2).

Validity: The validity of scale was calculated through internal consistency using Candle coefficient, which is $(0.895)$ as shown in table (3), which is considered high value in relation to this type of validity and emphasizes the internal consistency of the scale.

\section{Results}

Findings were analyzed using SPSS-V20 program.

The first hypothesis: "Kindergarten teachers have reasonable level of scientific competencies related to identification of normal child (skill of identifying the child with special needs skill of dealing with the child with special needs)"

The first domain: Identifying the child with special needs.

Table (5). Frequencies, percentages, value of K2 and its statistical significance for skills of kindergarten teachers for identifying the child with special needs

\begin{tabular}{|c|c|c|c|c|c|c|c|c|c|c|c|c|c|c|}
\hline \multirow{3}{*}{ Items } & \multicolumn{10}{|c|}{ Level of verification } & \multirow{3}{*}{$\begin{array}{l}\frac{7}{4} \\
\frac{0}{0} \\
\frac{0}{\pi} \\
\frac{\pi}{7}\end{array}$} & \multirow{3}{*}{ 莺 } & \multirow{3}{*}{$\sum_{\Sigma}^{\mathbb{E}}$} & \multirow{3}{*}{ 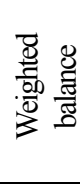 } \\
\hline & \multicolumn{2}{|c|}{$\begin{array}{l}\text { Strongly } \\
\text { agree }\end{array}$} & \multicolumn{2}{|c|}{ Agree } & \multicolumn{2}{|c|}{ Undecided } & \multicolumn{2}{|c|}{ Disagree } & \multicolumn{2}{|c|}{$\begin{array}{l}\text { Strongly } \\
\text { disagree }\end{array}$} & & & & \\
\hline & $\mathrm{K}$ & $\%$ & $\mathrm{~K}$ & $\%$ & $\mathrm{~K}$ & $\%$ & $\mathrm{~K}$ & $\%$ & K & $\%$ & & & & \\
\hline $\begin{array}{l}\text { Child with learning } \\
\text { disabilities suffers } \\
\text { from difficulty of } \\
\text { estimation of spaces } \\
\text { between lines }\end{array}$ & 40 & 26.67 & 59 & 39.33 & 41 & 27.33 & 2 & 1.33 & 8 & 5.33 & 77.67 & Agree & 3.81 & 76.13 \\
\hline $\begin{array}{l}\text { It is easy to identify } \\
\text { most people with } \\
\text { mental disabilities } \\
\text { through appearance }\end{array}$ & 24 & 16.00 & 52 & 34.67 & 46 & 30.67 & 25 & 16.67 & 3 & 2.00 & 51.00 & Agree & 3.46 & 69.20 \\
\hline
\end{tabular}




\section{Mll Macrothink}

International Research in Education

ISSN 2327-5499

2016, Vol. 4, No. 1

Excellent child has

skills that

distinguish him/her

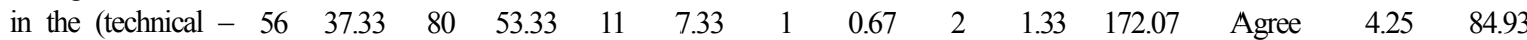

motor - linguistic -

mathematical)

aspects.

Child with disability

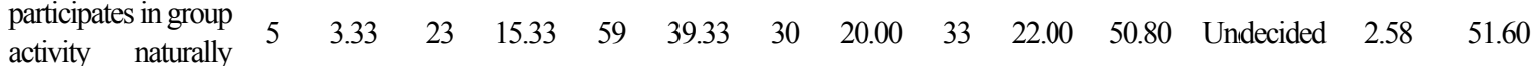

and effectively.

Child with learning

difficulties selects

similar numbers and

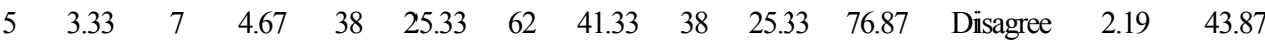

letters.

Child with mental

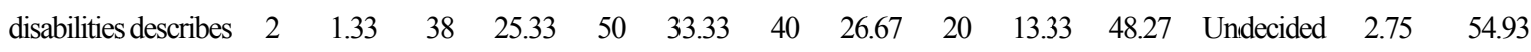

himself well.

Excellent child is

$\begin{array}{lllllllllllllll}\text { characterized by } & 63 & 42.00 & 43 & 28.67 & 23 & 15.33 & 1 & 0.67 & 20 & 13.33 & 74.93 & \text { Strongly } & 3.85 & 77.07 \\ \text { leadership skills. }\end{array}$

Child with mental

disabilities is

characterized by

$\begin{array}{lllllllllll}29 & 19.33 & 70 & 46.67 & 31 & 20.67 & 15 & 10.00 & 5 & 3.33 & 81.73\end{array}$

low intelligence.

Excellent child is

characterized by

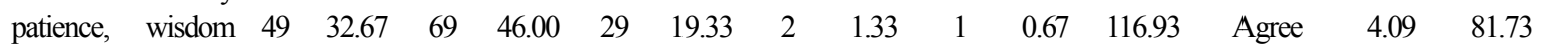

and seriousness in

his or her behaviors.

Child with learning

difficulties is

$\begin{array}{lllllllllllllll}\text { characterized by } & 41 & 27.33 & 56 & 37.33 & 33 & 22.00 & 15 & 10.00 & 5 & 3.33 & 55.20 & \text { Agree } & 3.75 & 75.07\end{array}$

excessive

movement.

Child with mental

disabilities uses

word-missing

$\begin{array}{llllllllllllllll}\text { sentences full of } & 26 & 17.33 & 68 & 45.33 & 35 & 23.33 & 5 & 3.33 & 16 & 10.67 & 76.87 & \text { Agree } & 3.55 & 71.07\end{array}$

grammatical

mistakes.

Excellent Child

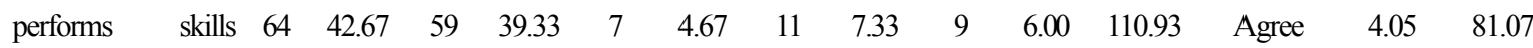

perfectly.

Child with learning

difficulties suffers

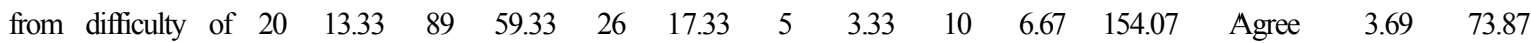

writing in a straight

line.

Child with mental

disabilities depends

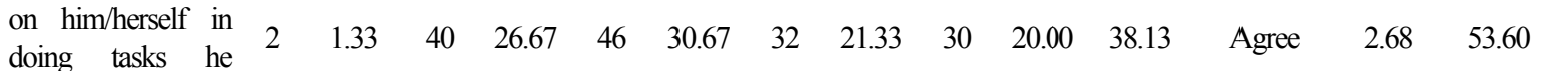

needs (clothing,

shoes and food) $\begin{array}{llllllllllllllll}\begin{array}{l}\text { Excellent child is } \\ \text { characterized by }\end{array} & 63 & 42.00 & 71 & 47.33 & 7 & .67 & 8 & 5.33 & 1 & 0.67 & 154.13 & \text { Agree } & 4.25 & 84.93\end{array}$ 
high level of

intelligence.

Child with learning

difficulties suffers

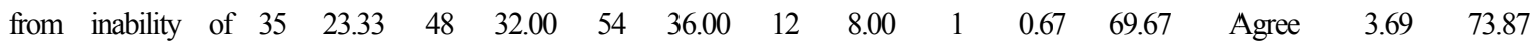

identifying

directions.

Child with mental

disabilities is able to

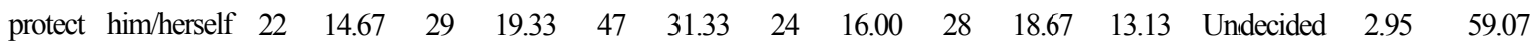

from risks that he or

she encounters.

Excellent child

performs the

instructions faste

$\begin{array}{llllllllllll}82 & 54.67 & 37 & 24.67 & 25 & 16.67 & 5 & 3.33 & 1 & 0.67 & 141.47 & \text { Strongly }\end{array}$

4.29

85.87

than others.

Child with learning

difficulties suffers

from inability to

master identifying

shape and size of

letters.

Child with mental

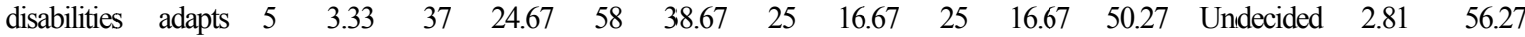

well with others.

Child with learning

difficulties suffers

from skill and

motor difficulties,

$\begin{array}{llllllllllllll}28 & 18.67 & 61 & 40.67 & 47 & 31.33 & 11 & 7.33 & 3 & 2.00 & 78.13 & \text { Agree } & 3.67 & 73.33\end{array}$

and sensory and

kinetic cooperation.

Child with mental

disabilities suffer

from academic

$\begin{array}{llllllllllllll}28 & 18.67 & 67 & 44.67 & 37 & 24.67 & 6 & 4.00 & 12 & 8.00 & 77.40 & \text { Agree } & 3.62 & 72.40\end{array}$

achievement.

Child with learning

disabilities suffers

$\begin{array}{llllllllllllllll}\text { from lack of } & 36 & 24.00 & 91 & 60.67 & 15 & 10.00 & 4 & 2.67 & 4 & 2.67 & 177.80 & \text { Agree } & 4.01 & 80.13\end{array}$

concentration and

inattention.

Child with learning

difficulties masters

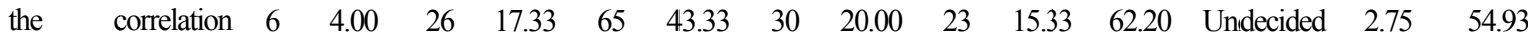

between written and

audible word.

Table (5) points out that the number of scientific competencies among kindergarten teachers to identify the child with special needs is high. Those who are (Agree) $=(15)$ out of (24) competencies i.e. $(62 \%)$.

The second domain: Kindergarten teachers' dealing with the child with special needs. 
Table (6). Frequencies, percentages, value of $\mathrm{K} 2$ and its statistical significance for kindergarten teachers' dealing with the child with special needs

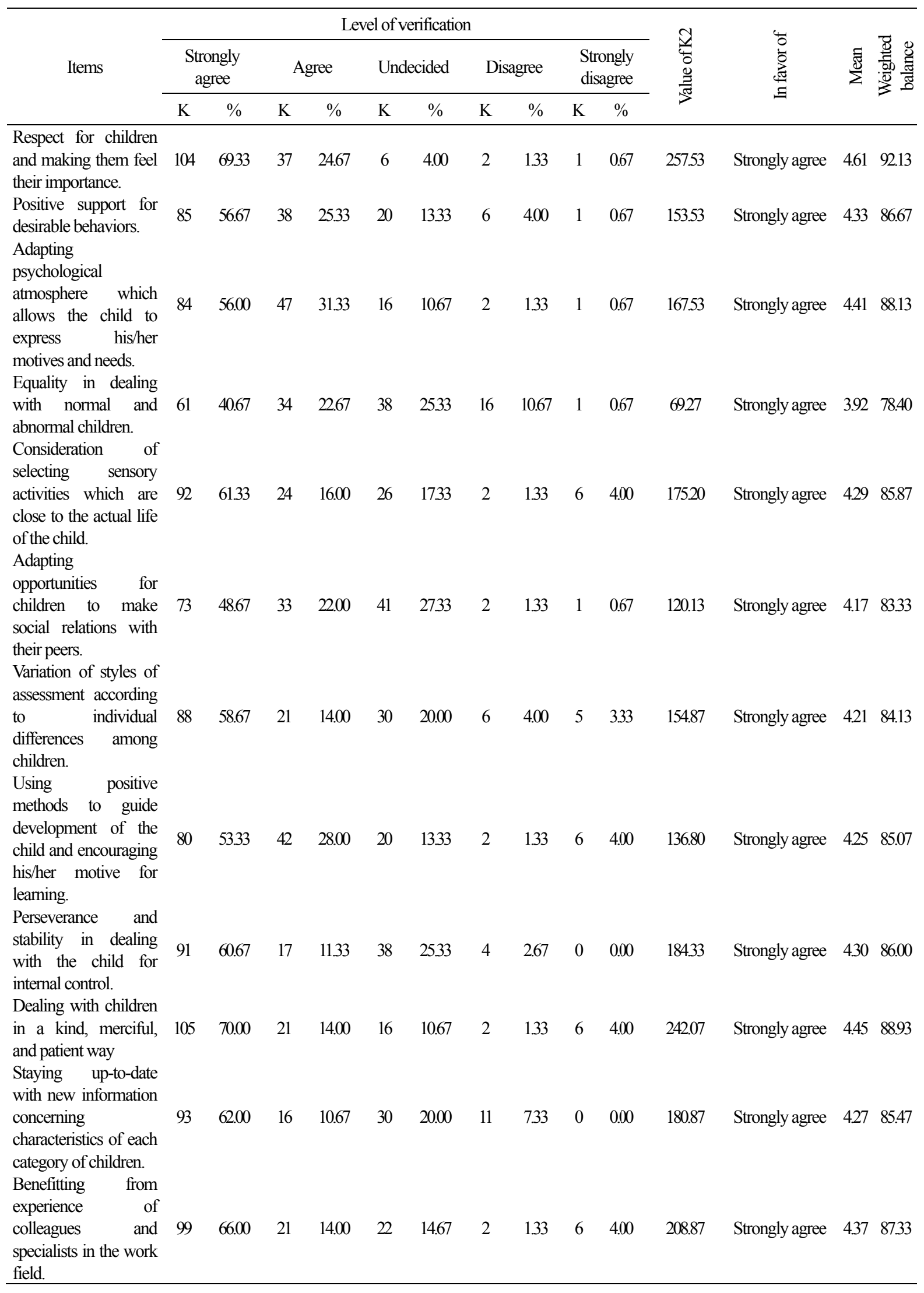


Sharing emotions with

children and

interacting with them

Benefitting from

individual learning

programs.

Showing daily care

for each child through

talking to or looking at

him/her.

Taking care of

individual learning

suitable for each child

according to his/her

needs.

Adapting all children

with reading and

writing according to

their capabilities and

abilities.

Consideration of the assessment of his/her capabilities using the simplest available resources.

Guiding the child to the health department to ensure safety of his/her senses.

Making a follow-up record to monitor his/her status to continuously provide him/her with feedback.

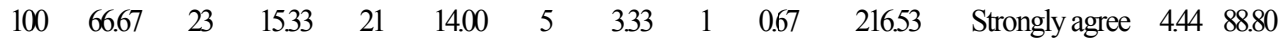

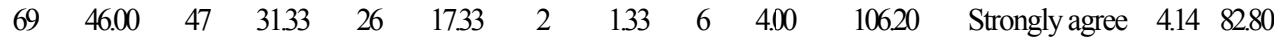

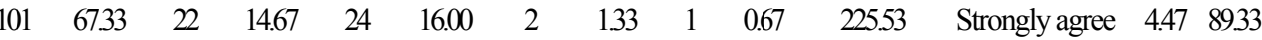

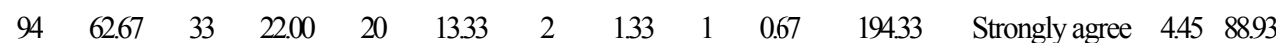

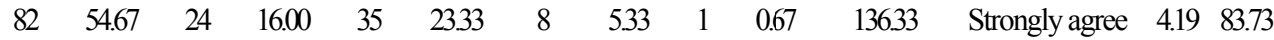

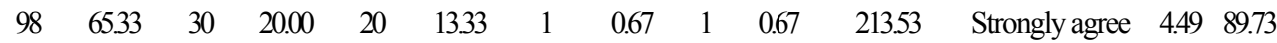

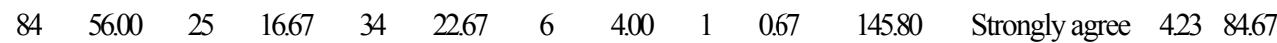

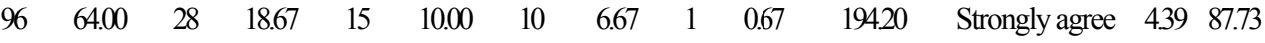

Table (6) shows that the number of scientific competencies related to the style of dealing with the child with special needs $=(20$ Strongly agree $)$ out of (20) scientific competencies with a percentage of $(100 \%)$, which represents high rate of competencies; this result indicates that kindergarten teachers have skills required for dealing with the child with special needs; also it refers to the teachers' recognition of these competencies, so the findings indicated that teachers have high level of these competencies.

Table (7). Frequencies, percentages and value of K2 and its statistical significance for the domains of the questionnaire of scientific competencies among kindergarten teachers to identify the child with special needs

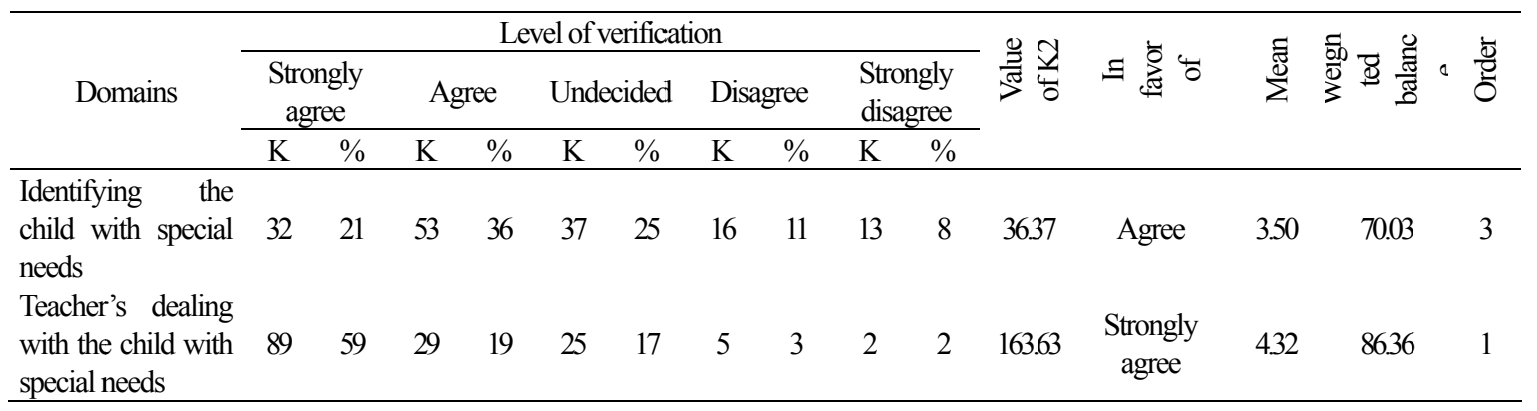


Table (7) indicates that the value of $\mathrm{K} 2$ is (36.37) and it is statistically significant at the level of (0.05) for the domain of identifying the child with special needs in favor of (Agree), where frequencies are (53) with a percentage of $(36 \%)$ that refers to the high degree of availability of scientific competencies among kindergarten teachers to identify the child with special needs; whereas the value of K2 was (163.63) which is statistically significant at the level (0.05) for the domain of dealing with the child with special needs in favor of "Strongly agree", where number of frequencies was (89) with percentage of (59\%), which indicates that kindergarten teachers have high level of availability of scientific competencies that verifies the first hypothesis, which indicates that the scientific competencies for identifying the child with special needs achieved high rates with a percentage lies between (62\%) and (100\%), which confirms that kindergarten teachers have scientific competencies to identify the children with special needs.

The second hypothesis: "There are statistical significant differences at the level of (0.05) between the means of the responses of kindergarten teachers on the scale of scientific competencies for identifying the child with special needs due to the variables of (specialization, years of work experience, and number of courses)". For examining the validity of this hypothesis, T-test was conducted for two means that are not correlated, as follows:

1) According to the variable of specialization:

Table (8). T-value for the significance of differences between the mean values of responses of kindergarten teachers in the questionnaire of scientific competencies among kindergarten teachers for identifying the child with special needs according to the variable of specialization

\begin{tabular}{|c|c|c|c|c|c|c|}
\hline Domains & specialization & $\begin{array}{l}\text { Mean } \\
\text { value }\end{array}$ & $\begin{array}{l}\text { Standard } \\
\text { Deviation }\end{array}$ & $\begin{array}{l}\text { Degree of } \\
\text { freedom }\end{array}$ & T-Value & $\begin{array}{l}\text { Significance } \\
\text { Level }\end{array}$ \\
\hline \multirow{2}{*}{$\begin{array}{l}\text { Identifying the child } \\
\text { with special needs }\end{array}$} & Kindergarten & & & \multirow{2}{*}{148} & \multirow{2}{*}{2.82} & \multirow{2}{*}{ Significant } \\
\hline & Other & 82.8190 & 7.32722 & & & \\
\hline \multirow{2}{*}{$\begin{array}{l}\text { Teacher's dealing with } \\
\text { the child with special } \\
\text { needs }\end{array}$} & Kindergarten & 95.3556 & 8.81929 & \multirow{2}{*}{148} & \multirow{2}{*}{5.06} & \multirow{2}{*}{ Significant } \\
\hline & Other & 84.8857 & 12.58304 & & & \\
\hline \multirow{2}{*}{ The scale as a whole } & Kindergarten & 182.6667 & 14.91339 & \multirow{2}{*}{148} & \multirow{2}{*}{5.10} & \multirow{2}{*}{ Significant } \\
\hline & Other & 167.7048 & 17.06319 & & & \\
\hline
\end{tabular}

* Significant at the level of (0.05)

Table (8) indicates that there are statistically significant differences at the level of (0.05) between mean values of responses of kindergarten teachers in the questionnaire of scientific competencies among kindergarten teachers for identifying the child with special needs according to the variable of specialization, the value of " $\mathrm{T}$ " was (5.10), which is statistically 
significant at the level of (0.05) in favor of the specialization of kindergarten, the thing that verifies the second hypothesis according to this variable.

2) According to the variable of years of work experience:

Table (9). Mean values and standard deviations of responses according to the variable of years of work experience

\begin{tabular}{|c|c|c|c|}
\hline Domains & Years of Experience & $\begin{array}{l}\text { Mean } \\
\text { value }\end{array}$ & $\begin{array}{l}\text { Standard } \\
\text { Deviation }\end{array}$ \\
\hline \multirow[t]{3}{*}{ Identifying the child with special needs } & Less than 5 years & 82.7596 & 7.43189 \\
\hline & $\begin{array}{c}\text { From } 5 \text { years to less than } 10 \\
\text { years }\end{array}$ & 97.1000 & 3.47851 \\
\hline & $\begin{array}{c}\text { From } 10 \text { years to less than } 15 \\
\text { years }\end{array}$ & 84.6389 & 11.59594 \\
\hline \multirow{3}{*}{$\begin{array}{l}\text { Teacher's dealing with the child with } \\
\text { special needs }\end{array}$} & Less than 5 years & 84.6635 & 12.46635 \\
\hline & $\begin{array}{c}\text { From } 5 \text { years to less than } 10 \\
\text { years }\end{array}$ & 99.0000 & 1.05409 \\
\hline & $\begin{array}{c}\text { From } 10 \text { years to less than } 15 \\
\text { years }\end{array}$ & 94.6944 & 9.77407 \\
\hline \multirow[t]{3}{*}{ The scale as a whole } & Less than 5 years & 167.4231 & 16.89872 \\
\hline & $\begin{array}{c}\text { From } 5 \text { years to less than } 10 \\
\text { years }\end{array}$ & 196.1000 & 4.48330 \\
\hline & $\begin{array}{c}\text { From } 10 \text { years to less than } 15 \\
\text { years }\end{array}$ & 179.3333 & 14.74158 \\
\hline
\end{tabular}

Table (10). One-way analysis of variance for differences of responses of kindergarten teachers in the questionnaire of scientific competencies among kindergarten teachers for identifying the child with special needs according to the variable of years of experience

\begin{tabular}{|c|c|c|c|c|c|c|}
\hline Domains & Source of variance & $\begin{array}{l}\text { Sum of } \\
\text { squares }\end{array}$ & $\begin{array}{l}\text { Degrees } \\
\quad \text { of } \\
\text { freedom }\end{array}$ & $\begin{array}{c}\text { Mean } \\
\text { values of } \\
\text { squares }\end{array}$ & $\begin{array}{l}\text { Value } \\
\text { of "F" }\end{array}$ & $\begin{array}{l}\text { Significance } \\
\text { Level }\end{array}$ \\
\hline \multirow{4}{*}{$\begin{array}{l}\text { Identifying the child } \\
\text { with special needs }\end{array}$} & Between groups & 1886.637 & 2 & 943.319 & \multirow{3}{*}{13.201} & \multirow{3}{*}{.000} \\
\hline & Within groups & 10504.196 & 147 & 71.457 & & \\
\hline & Total variance & 12390.833 & 149 & & & \\
\hline & Between groups & 3981.033 & 2 & 1990.517 & \multirow{3}{*}{15.113} & \multirow{3}{*}{.000} \\
\hline \multirow{2}{*}{$\begin{array}{l}\text { Teacher's dealing with } \\
\text { the child with special } \\
\text { needs }\end{array}$} & Within groups & 19360.860 & 147 & 131.707 & & \\
\hline & Total variance & 23341.893 & 149 & & & \\
\hline \multirow[t]{3}{*}{ The scale as a whole } & Between groups & 9917.109 & 2 & 4958.554 & & \multirow{3}{*}{.000} \\
\hline & Within groups & 37200.285 & 147 & 253.063 & 19.594 & \\
\hline & Total variance & 47117.393 & 149 & & & \\
\hline
\end{tabular}


Table (10) shows that there are statistically significant differences between the mean values of responses of kindergarten teachers in the questionnaire of scientific competencies among kindergarten teachers for identifying the child with special needs according to the variable of years of experience (less than 5 years, from 5 years to less than 10 years, and from 10 years to less than 15 years), statistically significant in favor of years of experience (from 5 years to less than 10 years), that verifies the second hypothesis according to this variable.

3) According to the variable of number of training courses:

T-test was conducted to examine the validity of the 2 nd hypothesis according to the variable of training courses.

Table (11). T-value for the significance of differences between the mean values of responses of kindergarten teachers in the questionnaire of scientific competencies among kindergarten teachers for identifying the child with special needs according to the variable of number training courses

\begin{tabular}{|c|c|c|c|c|c|c|}
\hline Domains & $\begin{array}{l}\text { No. of } \\
\text { Courses }\end{array}$ & $\begin{array}{l}\text { Mean } \\
\text { value }\end{array}$ & $\begin{array}{l}\text { Standard } \\
\text { Deviation }\end{array}$ & $\begin{array}{l}\text { Degree of } \\
\text { freedom }\end{array}$ & T-Value & $\begin{array}{l}\text { Sig. } \\
\text { Level }\end{array}$ \\
\hline \multirow{2}{*}{$\begin{array}{l}\text { Identifying the child with } \\
\text { special needs }\end{array}$} & $1-5$ & 83.9279 & 8.86127 & \multirow[b]{2}{*}{148} & \multirow[b]{2}{*}{0.540} & \multirow[b]{2}{*}{$\begin{array}{l}\text { Not } \\
\text { Sig. }\end{array}$} \\
\hline & $6-10$ & 84.8462 & 9.90624 & & & \\
\hline \multirow{2}{*}{$\begin{array}{l}\text { Teacher's dealing with the } \\
\text { child with special needs }\end{array}$} & $1-5$ & 86.0631 & 12.95677 & \multirow[b]{2}{*}{148} & \multirow[b]{2}{*}{3.35} & \multirow[b]{2}{*}{ Sig. } \\
\hline & $6-10$ & 93.6154 & 9.21845 & & & \\
\hline \multirow{2}{*}{ The scale as a whole } & $1-5$ & 169.9910 & 18.48513 & \multirow{2}{*}{148} & \multirow{2}{*}{2.60} & \multirow{2}{*}{ Sig. } \\
\hline & $6-10$ & 178.4615 & 14.01098 & & & \\
\hline
\end{tabular}

Significant at the level of (0.05).

Table (11) indicates that there are statistically significant differences between the mean values of responses among kindergarten teachers in the questionnaire of scientific competencies to identify the child with special needs according to the variable of number of training courses (from 1-5 courses, from 6-10 courses) either on the level of each domain of the questionnaire or the total domains at the level of (0.05), where the value of " $T$ " is (2.60), which is statistically significant in favor of the number of courses ranged from (6-10) courses, which verifies the second hypothesis according to this variable, which indicates that kindergarten teachers have the highest level of skills of scientific competencies for identifying the child with special needs with the increase of the number of training courses.

The third hypothesis: "There are statistical significant differences at the level of (0.05) between the means of the responses of kindergarten teachers on the scale of the attitude towards the child with special needs due to the variables of (specialization, years of work experience, and number of courses)." 
Table (12). T-value for the significance of differences between the mean values of responses of kindergarten teachers for the scale of the attitude towards the child with special needs

\begin{tabular}{llllllll}
\hline Variable & & $\begin{array}{l}\text { Mean } \\
\text { Value }\end{array}$ & $\begin{array}{l}\text { Standard } \\
\text { Deviation }\end{array}$ & $\begin{array}{l}\text { Degree } \\
\text { freedom }\end{array}$ & of & T-Value & Sig. Level \\
\hline \multirow{2}{*}{ Specialization } & Kindergarten & 88.3556 & 9.19772 & & & \\
& Other & 82.3810 & 11.04830 & 148 & 3.18 & Significant \\
& $\begin{array}{l}\text { Less than 5 years } \\
\text { Years }\end{array}$ & 82.0577 & 10.81784 & & & \\
$\begin{array}{l}\text { Experience } \\
\text { of }\end{array}$ & $\begin{array}{l}\text { From 5 years to less } \\
\text { than 10 years }\end{array}$ & 91.5000 & 4.74342 & 148 & 3.35 & Significant \\
& $\begin{array}{l}\text { From 10 years to less } \\
\text { than 15 years }\end{array}$ & 88.2500 & 10.26053 & & & \\
1-5 & $8-10$ & 83.8829 & 9.81348 & 148 & 0.552 & Not Sig. \\
\hline
\end{tabular}

Table (12) reveals that there are statistically significant differences between responses of kindergarten teachers on the scale of attitude towards the child with speciial needs according to the variables of the specialization and years of experience, which are significant at the level (0.05), and T-value is (3.18), (3.35) respectively, which is statistically significant in favor of specialization of kindergarten and years of experience (from 6 years to less than 10 years); that verifies the third hypothesis concerning these variables; as for the variable of training courses, T-value is statistically non-significant.

The fourth hypothesis: "There is a positive correlation between the scores of Kindergarten teachers for scientific competencies related to the child with special needs and their scores on the scale of the attitude towards that child."

Pearson correlation coefficient was calculated between the sample scores for scientific competencies, as shown in the following table:

Table (13) shows R-Value and its statistical significance of the correlation relationship among scores of the respondents for scientific competencies for identifying the children with special needs and their scores on the scale of the attitude towards them

\begin{tabular}{lll}
\hline \multicolumn{1}{c}{$\begin{array}{l}\text { Identifying } \\
\text { child with special } \\
\text { needs }\end{array}$} & $\begin{array}{l}\text { Kindergarten female } \begin{array}{l}\text { The scale of Kindergarten } \\
\text { Teacher's dealing female teachers' attitude } \\
\text { with the child with } \\
\text { special needs }\end{array} \\
\text { towards the child with } \\
\text { special needs }\end{array}$ \\
$\begin{array}{l}\text { Identifying the child with special } \\
\text { Keeds } \\
\text { Kindergarten female Teacher's } \\
\text { needs }\end{array}$ & $0.92^{*}$ & $0.77^{*}$ \\
$\begin{array}{l}\text { The scale of Kindergarten female } \\
\text { teachers' attitude towards the child } \\
\text { with special needs }\end{array}$ & & \\
\hline
\end{tabular}


Table (13) illustrates that there is a positive significant correlation at the level of (0.05) between the scale of scientific competencies for kindergarten teachers and the scale of kindergarten teachers' attitude towards the children with special needs, where value of " $R$ " = (0.92 and 0.77 ) respectively, which is statistically significant at the level of $(0.05)$. There is also a positive significant correlation at the level of (0.05) between the second domain "Kindergarten female Teacher's dealing with the child with special needs" and "the scale of Kindergarten female teachers' attitude towards the child with special needs", where value of $" R "=(0.81)$, which is statistically significant at the level of $(0.05)$ - this verifies the fourth hypothesis.

\section{Discussion}

The findings of the present study concluded that:

1) Kindergarten teachers enjoy high level of availability of scientific competencies related to the skills of identifying the child with special needs and very high level of skills of dealing with the child with special needs, either on the level of domains or on the level of the questionnaire as a whole.

2) There are statistically significant differences at the level of (0.05) between responses of kindergarten teachers according to the variables of "specialization, years of experience and number of training courses", totally in favor of the specialization of kindergarten, average years of experience and number of training courses, ranged from (6-10) courses, which verifies the second hypothesis; so the more are years of experience, training courses and workshops and the more is the teacher specialized in the field, the more is the scientific competencies of teachers to identify the child with special needs.

3) There are statistically significant differences between responses of kindergarten teachers due to variables of experience and specialization, there is no evidence that there is a statistical significance for the variable of training courses, that is, according to the viewpoints of the two authors, due to the inefficiency of the training courses that the teachers got, as these courses focus on the theoretical aspects only rather than experimental ones (workshops), so they have no effect on the attitudes of kindergarten teachers. This result is in consistent with the study of Yaseen (2003i).

4) Table (13) indicates that there is a positive significant correlation at the level of (0.05) between the scale of scientific competencies for kindergarten teachers and the scale of kindergarten teachers' attitude towards the children with special needs, where value of " $R "=(0.92$ and 0.77$)$ respectively, which is statistically significant at the level of $(0.05)$ - that verifies the fourth hypothesis.

The two authors explain the results mentioned above in the light of many factors, the most important of these factors are the following:

- The course of "Education of Students with Special Needs in Regular Schools" should be included within the program's courses of kindergarten in Najran, which shows the characteristics of each category of children with disability. There is no doubt that these courses can be skillful, cognitive and behavioral background, which ensures 
graduation of specialized teachers that have the ability of dealing with, guiding and orienting different categories of people with disabilities; this has a positive effect on modifying their attitudes towards this category. The study of Abo-alnor (2009) confirms the importance of the academic curricula and courses for students and their positive attitudes towards the integration of people with disabilities.

- Information related to the children with special needs, which can be acquired with the increasing years of experience and attendance of more training courses related to the field of special needs. Al-Shakhs (1990) assured that the more information increased about those of special needs, the more this led to positive attitudes towards them. The information related to the field of special needs plays an important role in modification of the attitudes of individuals towards the positive ones. Also, Yuker (1994) indicated in his study that information and communication are considered important factors which affect the attitudes towards people with disabilities.

- Actual contact between kindergarten teachers and the children with special needs and dealing with them is an important factor which affects the attitudes towards those of special needs. Yuker (1994) proved that communication or contact with people with special needs can acquire positive or negative attitudes; he indicated that communication via social relationships can often lead to positive attitudes; however contact through temporary relationships often leads to negative attitudes; the findings of this study correspond to that of Chen (2002), which examined university students in US and Taiwan and proved that past experiences of contact with people with special needs of the individuals of the two samples demonstrated that such a variable was a factor in acquiring positive attitudes towards those people of special needs, compared to individuals that never contacted with people with special needs, as they showed that they have negative attitudes towards people with disabilities.

The results of the current study are in consistent with the study of Ali \& Abdelkarim (2010), and the study of Alholi, Johar, and Alqalaf (2005) which concluded that the variable of experience has an important effect on the level of the availability of competencies for kindergarten teachers in favor of experience which is (more than 6 years). Cook, B. G., et al. (2000) emphasized that the more is the teaching experience of teachers, the more are their attitudes towards people with disabilities; this corresponds to the research findings of Al-Deeb (2013) and Alfaiez (1996) which confirmed the importance of training; the research findings concluded that teachers who participated in more training courses have more positive attitudes towards the integration than their counterparts who participate in one course.

The results of the current study is inconsistent with the studies of Yaseen (2001), Alkersh (1990) and Alnadi (1987) which concluded that there is no relation between number of years of experience in the field of kindergarten and availability of main competencies of teachers, although they emphasized on the importance of training.

\section{Recommendations}

(1) Each kindergarten should have an expert in the field of special education, who works in 
coordination with teachers as a reference providing them with information and applicable methods that should be followed in case of encountering any problems.

(2) Benefitting from scientific competencies in the design of programs for qualification of kindergarten teachers, and in planning their training programs during work.

(3) Focusing on improving the efficiency of the scientific aspect for the teacher by increasing the number of courses, along with being quantitatively and qualitatively successful, continuous training and encouraging them for occupational growth personally and continuously.

(4) Qualifying the teacher student in a way that enables her to understand the people with disabilities and with special needs, considering both the theoretical and practical aspects.

(5) Modification of the attitudes of teachers and normal children towards children with special needs before conducting the integration process.

\section{Acknowledgments}

The authors of the current study are indebted to the Deanship of the Scientific Research at Najran University, K.S.A for funding this research project.

\section{References}

Abdul-Haq, Z. I. (2014). The Educational Skills Required for Kindergarten Teachers in Jordan. American Journal of Educational Research, 2(3), 159-166. http://dx.doi.org/10.12691/education-2-3-9

Abehery, A. (2004). Proposal for the integration of children with mental disabilities and behavioral and emotional disorders with normal children, Eleventh Annual Conference, Psychological Guidance Center, Ain Shams University, Youth for better future, Psychological guidance and challenges. Development, 25-27 December, pp. 899-917.

Abo Harb, Y. H. (2005). Teaching competencies required for preschool teachers in the light of the development of curriculum forms in the twenty first century, in the conference of children and youth in the Middle East and North Africa, Dubai, United |Arab Emirates, 17-19 April, 2005, pp. 52-87.

AlDeeb, R. (2013). Problems facing integration process of children with special needs, $1^{\text {st }}$ Scientific Conference - College of Education, Department of Mental Health, Benha University, 1-3 July.

Alfaiez, H. (1996). The attitudes of kindergarten teachers towards the integration of children with special needs with normal children in kindergarten institutions and their relationship with their professional performance. Master thesis, King Saud University, Faculty of Education.

Al-Haroun, M. (2006). Comparative study of the qualification and training of kindergarten teachers with special needs in Egypt and the developed countries, Port Said University "project of the establishment of database for studies and researches related to kindergarten, 
Kindergarten College, on the level of Egyptian universities.

Alholi, J., \& Alqallaf. (2005). Personal and professional competencies of kindergarten teachers: College of Primary Education, Kuwait.

Alkersh, M. (1990). Some scientific competencies required for kindergarten teachers, the $2^{\text {nd }}$ International Scientific Conference for Qualification of Teachers, (15-18) June. Journal of Egyptian Society for Curricula and Instruction, 3, 1127-1138.

Alnadi, A. (1987). Main performance competencies and their availability for kindergarten teachers. Unpublished MA, Faculty of Education, Helwan University, Egypt.

Al-Qaryouty, Y., et al. (1998). Introduction of special education, Dubai. Dar Elkalam.

Alsaiegh, A. (2011). Comparative study of attitudes of university students and special education teachers towards the integration and processing of people with disabilities. Journal of Psychological Studies, 21(3).

Alsamadi, A. (2007). Attitudes of teachers towards integration of students with disabilities in the first three grades with normal children in the governorate of Arar, Journal of University of Islamic Sciences, Gaza.

Al-Shakhs, A. (1990). The effect of information on the change of attitudes towards people with disabilities, Journal of the University of King Saud, Educational Sciences, Riyadh (pp. 77-99).

Altomy, A. (2005). Competencies: systematic coordination. Dar Elhelal, 3, Morocco, p. 28

Block, M. E., \& Rizzo, T. L. (1995). Attitudes and attributes of physical educators associated with teaching individuals with severe and profound disabilities. Journal of the Association of People with Severe Handicaps, 20(1), 80-87. http://dx.doi.org/10.1177/154079699502000108

Chen, R. K. (2002). Attitudes toward people with disabilities in the Social Context of Dating and Marriage: A Comparison of American, Taiwanese and Singaporean College Students, National Rehabilitation Association. Retrieved from www.findarticles.com

Cook, B. G.,Tankersley, M., Cook, L., \& Landrum, T. J. (2000). Teacher's attitudes towards their included students with disabilities. SAGE Publications: Exceptional Children, 67(1), 115-135.

Curran, J. M. (1999). Changing attitudes toward people with mental retardation: Effects of extended contact within a changing social context. Eric. Retgrieved from http://orders.erds.com/members/sp.cfm?AN=ED443314

Hawkins, G. (1991). Attitude Toward Mainstreaming Students With Disabilities Among Regular Elementary Music and Physical Educators. Dep. of Physical Education, University of Maryland College park, Maryland, USA.

James et al. (2009) Developing Teacher Skills In Light Of Educational Competency.

Jawarneh, R. (2003). The attitudes of teachers towards the integration of children with special 


\section{Macrothink}

International Research in Education

ISSN 2327-5499 2016, Vol. 4, No. 1

needs in the first four grades. Unpublished MA, Jordan: Alyarmok University, college of Physical Education.

Katie, G. J., \& Ron, F. (1995). Attitudes of Physical Educators Toward the integration of handicapped Students, perceptual and motor skills.

Kis-Glavas, Lelia; et al. (1996). Teacher's attitudes toward the integration of pupils with intellectual disabilities. Eric. Retrieved from http://orders.edrs.com/members/ sp. cfm?AN $=$ ED408751

Praisner, C. L. (2003). Attitudes of elementary school principals toward the inclusion of students with disabilities, Exceptional Children, 69(2), 135-145. http://dx.doi.org/10.1177/001440290306900201

Quebec Education Program - Preschool Education (2002). Retrieved April 5, 2002, from http://www.meq.gouv.qc.ca//virage/publications/prog-form-preschool-a.htm

Yaseen, N. (2003). Assessment of the skills of kindergarten teachers in Makah, faculty of Education, Umm Alqurah University.

Yuker, H. E. (1994). Variables that Influence Attitudes toward People with Disabilities. Journal of Social Behavior and Personality, 9(5), 3-22.

\section{Copyright Disclaimer}

Copyright reserved by the authors.

This article is an open-access article distributed under the terms and conditions of the Creative Commons Attribution license (http://creativecommons.org/licenses/by/3.0/). 